\title{
ANALISIS SIDIK CEPAT KERAWANAN LONGSOR LAHAN DI KAWASAN PERTAMBANGAN TANAH URUG
}

\author{
Primanda Kiky Widyaputra ${ }^{1)}$, Dwi Herniti ${ }^{2)}$ \\ 1) 2) Fakultas Teknologi Sumber Daya Alam, Institut Teknologi Yogyakarta \\ email: primandakiky@ gmail.com ${ }^{1)}$
}

\begin{abstract}
ABSTRAK
Kegiatan pertambangan tanah urug pada topografi yang berbukit memiliki potensi terjadi longsor lahan. Suatu kejadian longsor lahan pada kegiatan pertambangan dapat menimbulkan kerugian baik berupa material ataupun korban jiwa, sehingga diperlukan kajian sebagai upaya mitigasi dan pengurangan risiko longsor di kawasan pertambangan tanah urug. Tujuan dari penelitian ini adalah 1) mengidentifikasi lokasi potensi longsor lahan di kawasan pertambangan tanah urug Kabupaten Bantul; dan 2) menganalisis faktor longsor lahan secara sidik cepat di kawasan pertambangan tanah urug Kabupaten Bantul. Identifikasi potensi longsor dilakukan melalui pendekatan spasial guna memperoleh informasi kerawanan longsor secara sidik cepat. Metode identifikasi lokasi berpotensi longsor dilakukan dengan pengamatan kelerengan, penggunaan lahan, geologi dan tanah. Hasil analisis sidik cepat, adanya kejadian longsor terdahulu, pemodelan lereng, dan pengamatan lapangan menunjukkan potensi kerawanan longsor lahan terdapat di kawasan pertambangan tanah urug di Dusun Karangtalun, Wukirsari, Imogiri, Bantul, dan faktor longsor lahan adalah dari faktor topografi dan lereng.
\end{abstract}

Kata Kunci : Pertambangan, Sidik Cepat, Longsor

\section{RAPID ASSESSMENT ANALYSIS OF LANDSLIDE SUSCEPTIBILITY IN SOIL MINING AREA}

Soil mining activity has the potential of landslide resulting losses of housing or casualties. It takes effort to mitigating and reducing the risk of landslide by identifying susceptible location. Therefore, the purposes of this research are 1) to identify the landslide potential location in soil mining area in Bantul Regency and 2) to analyze landslide factors using rapid assessment in soil mining area, Bantul Regency. Identification was done using spatial approach to get landslide potential location. Methods of identification of landslide factors was gather using observation of landuse, topography, geology and soil. The results from rapid assessment, previous landslide occurrence, slope model, and filed observation show potential landslide location is located in Karangtalun, Wukirsari, Imogiri, Bantul, with dominant factor is from topography and slope.

Keywords : Mining, Rapid Assessment, Landslide

\section{Latar Belakang}

Pertambangan tanah urug, pasir dan batuan termasuk jenis usaha pertambangan yang umum dijumpai di Kabupaten Bantul yang bertujuan digunakan untuk berbagai keperluan pembangunan di DIY, khususnya adanya pembangunan bandara baru yang masih membutuhkan suplai tanah urug (Nariswari, 2017). Kegiatan penambangan ini dapat menimbulkan dampak positif maupun negatif, sehingga pemanfaatan sumberdaya alam tersebut harus dilakukan secara efektif agar dapat berkelanjutan.

Tanah longsor dan gerakan tanah didefinisikan sebagai massa tanah atau material campuran lempung, kerikil, pasir, dan kerakal serta bongkah dan lumpur yang bergerak sepanjang lereng atau keluar lereng karena faktor gravitasi. Faktor-faktor pengontrol pergerakan tanah diantaranya adanya getaran dan gangguan yang memicu terjadinya gerakan, keberadaan air yang meresap ke dalam tanah dan kontak air dengan bidang gelincir (Karnawati, 2005).

Identifikasi kerawanan longsor pada kawasan pertambangan tanah urug perlu diperhatikan untuk mengurangi risiko dan mendukung kegiatan yang sedang dilakukan. Identifikasi dan analisis kerawanan longsor dapat dilakukan melalui pendekatan sidik cepat. Sidik cepat merupakan analisis secara bertahap pada parameter-parameter utama suatu kejadian, sehingga dapat diketahui potensi bahaya yang dapat timbul (Widyaputra, 2015). 
Pergerakan tanah terjadi saat gaya pendorong pada lereng lebih besar dari gaya penahan. Gaya penahan dapat dipengaruhi oleh kekuatan batuan dan kepadatan tanah, sedangkan gaya pendorong dipengaruhi oleh intensitas hujan yang tinggi, beban lereng, berat jenis tanah, dan besar sudut lereng (Ganda, 2012; Verruijt, 2017).

Suatu kejadian longsor lahan pada kegiatan penambangan dapat menimbulkan kerugian baik berupa material ataupun korban jiwa. Kejadian longsor pada suatu DAS juga seringkali berasosiasi dengan kejadian banjir (Brook, 1991). Penelitian ini bertujuan mengidentifikasi faktor potensi longsor lahan secara sidik cepat di kawasan pertambangan tanah urug di Kabupaten Bantul.

\section{Metode Penelitian}

Penelitian dilakukan dengan pendekatan multi skala, yaitu menggunakan analisis spasial menggunakan Sistem Informasi Geografis dari data google earth, Peta Geologi Lembar DIY, dan kontur DIY untuk identifikasi awal. Analisis menggunakan SIG dan penginderaan jauh digunakan untuk menentukan lokasi potensi kejadian secara spasial (Kusratmoko, 2002; Rudiyanto, 2010). Selanjutnya dipilih lokasi yang akan dilakukan pengamatan lapangan lebih lanjut. Dari lokasi terpilih akan dilakukan analisis dengan skala yang lebih detil.

Parameter yang dilihat pada pengamatan lapangan meliputi kelerengan, penggunaan lahan, jenis geologi dan tanah. Analisis dilakukan secara sidik cepat (rapid assessment) dalam menilai kerawanan bahaya. Analisis sidik cepat diharapkan dapat mendukung diperolehnya informasi kerawanan longsor relatif lebih cepat dan dengan data yang terbatas (Widyaputra, 2015). Tahapan kegiatan penelitian ini meliputi:

\section{Tahap Pra-Survei}

(1) Pengorganisasian alat-alat penelitian dan rencana survei

(2) Pengumpulan data sekunder dan penentuan lokasi pengamatan awal

(3) Analisis spasial untuk menentukan lokasi observasi

Tahap Penelitian Lapangan

(1) Analisis spasial kondisi eksisting

(2) Observasi lapangan, pengamatan kondisi topografi, kelerengan, pengamatan geologi dan tanah

Tahap Penyelesaian

(1) Pengolahan data hasil pengamatan

(2) Penyusunan peta dan model lereng

(3) Interprestasi hasil analisis data lapangan secara deskriptif

(4) Penyusunan laporan 


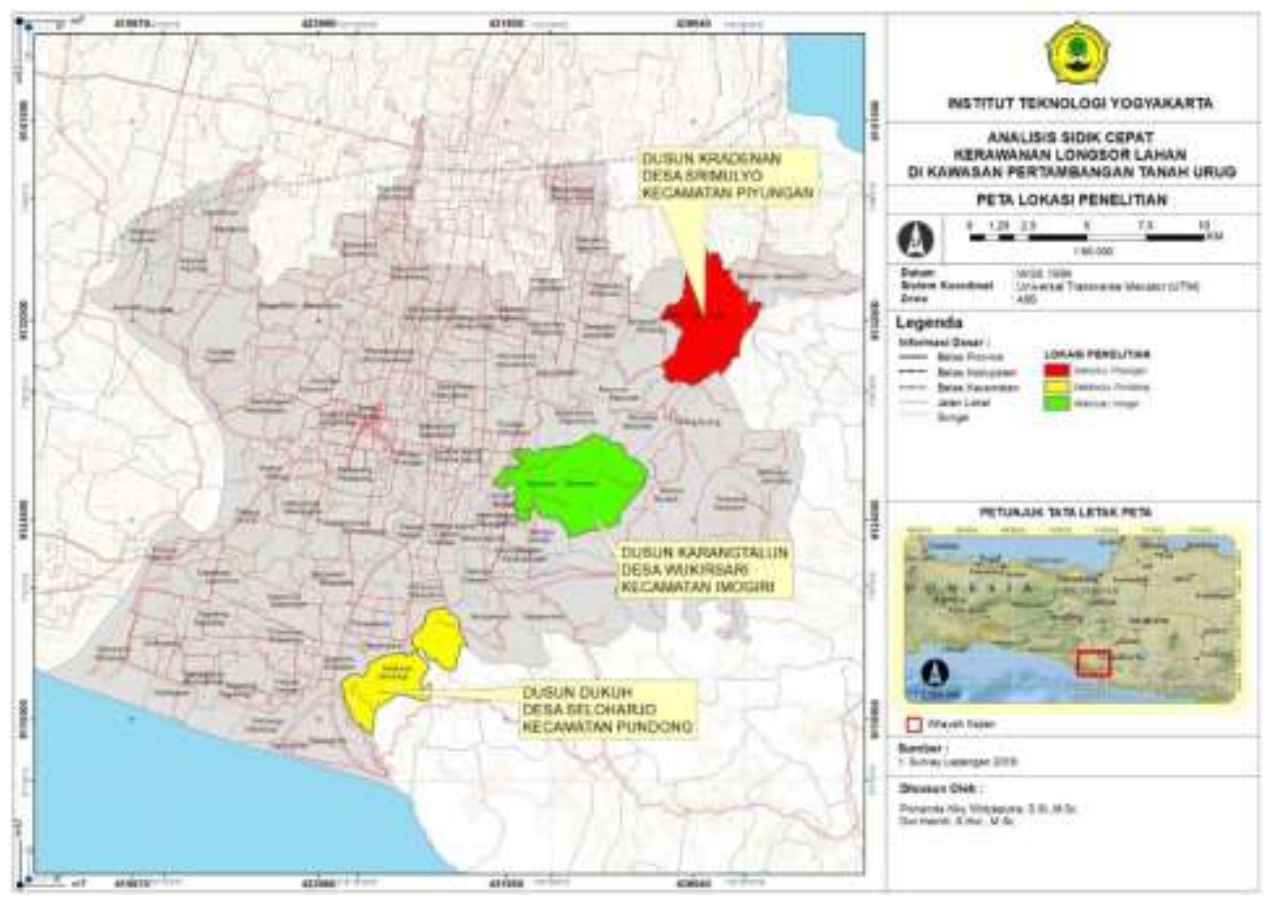

Gambar 1. Lokasi Penelitian

\section{Hasil dan Pembahasan}

Kegiatan penambangan tanah urug pada topografi yang berbukit memiliki potensi terjadi longsor lahan, sehingga perlu memperhatikan potensi bahaya, memperhatikan kaidah metode penambangan yang baik (good mining practice) dan memperhatikan aturan daerah setempat serta memiliki izin usaha pertambangan (Peraturan Daerah Daerah Istimewa Yogyakarta Nomor 1 Tahun 2018).

Penelitian ini dilakukan secara multi skala yaitu dengan menentukan lokasi pengamatan awal di tiga lokasi di Kabupaten Bantul yaitu Dusun Kradenan Desa Srimulyo, Dusun Karangtalun Desa Wukirsari, dan Dusun Dukuh Desa Seloharjo. Pertimbangan pemilihan lokasi adalah berdasarkan data yang diperoleh dari kecamatan terkait. Pengambilan tiga lokasi dilakukan sebagai perbandingan kondisi dari beberapa kecamatan yang berbeda.

Berdasarkan analisis spasial dan pengamatan lapangan awal di tiga lokasi penambangan tanah urug di Kabupaten Bantul tersebut, dijumpai bahwa lokasi yang akan dianalisis lebih lanjut adalah di Dusun Karangtalun Desa Wukirsari. Pemilihan tersebut dilihat dari kondisi topografi yang cenderung berbukit, adanya kegiatan tambang yang aktif, dan kedekatan dengan permukiman. 


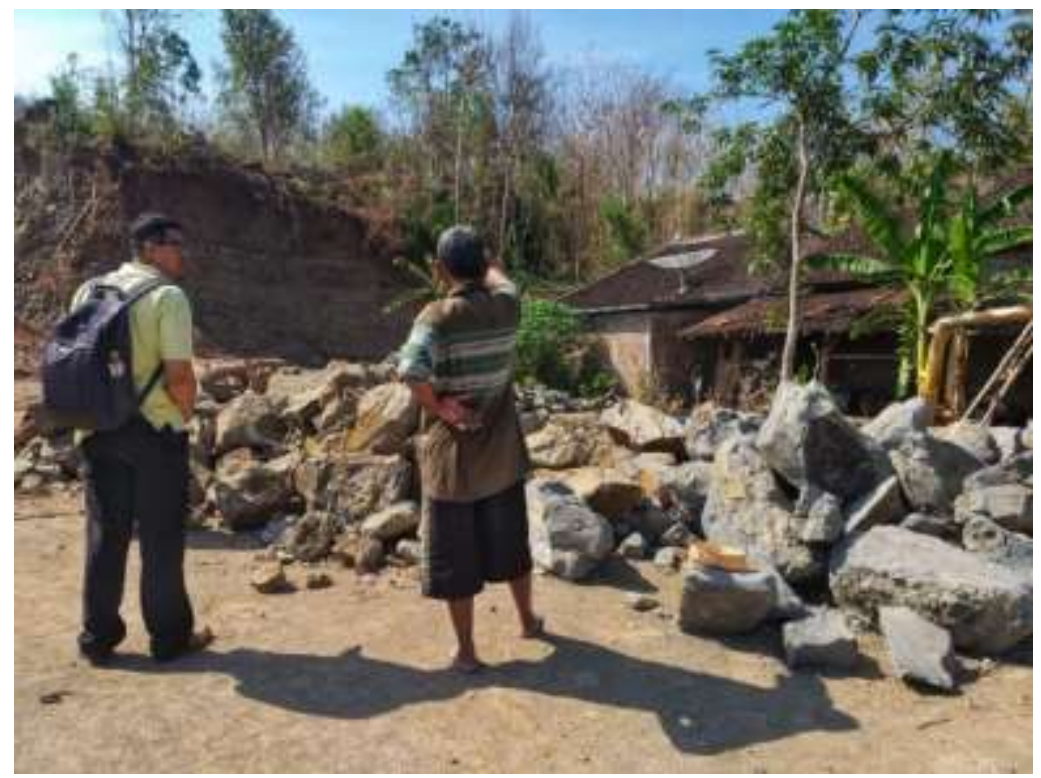

Gambar 2. Sisa Perbukitan di Lokasi Tambang

Pengamatan kondisi eksisting, citra satelit time series serta hasil wawancara mendalam dengan masyarakat di lokasi menunjukkan hasil bahwa sebelum dilakukan kegiatan penambangan tanah urug, kondisi lahan berupa perbukitan dengan tingkat kelerengan yang curam. Terdapat bukti kejadian longsor dan banjir yang terjadi pada saat sebelum adanya kegiatan penambangan tanah urug.

Kegiatan penambangan tanah urug di lokasi ini masih menyisakan beberapa bagian yang curam dan dapat berpotensi longsor apabila terjadi hujan dengan intensitas sering dan lebat. Posisi rumah/ permukiman relatif dekat dengan bukit $(<10$ meter $)$ sehingga berisiko terdampak.

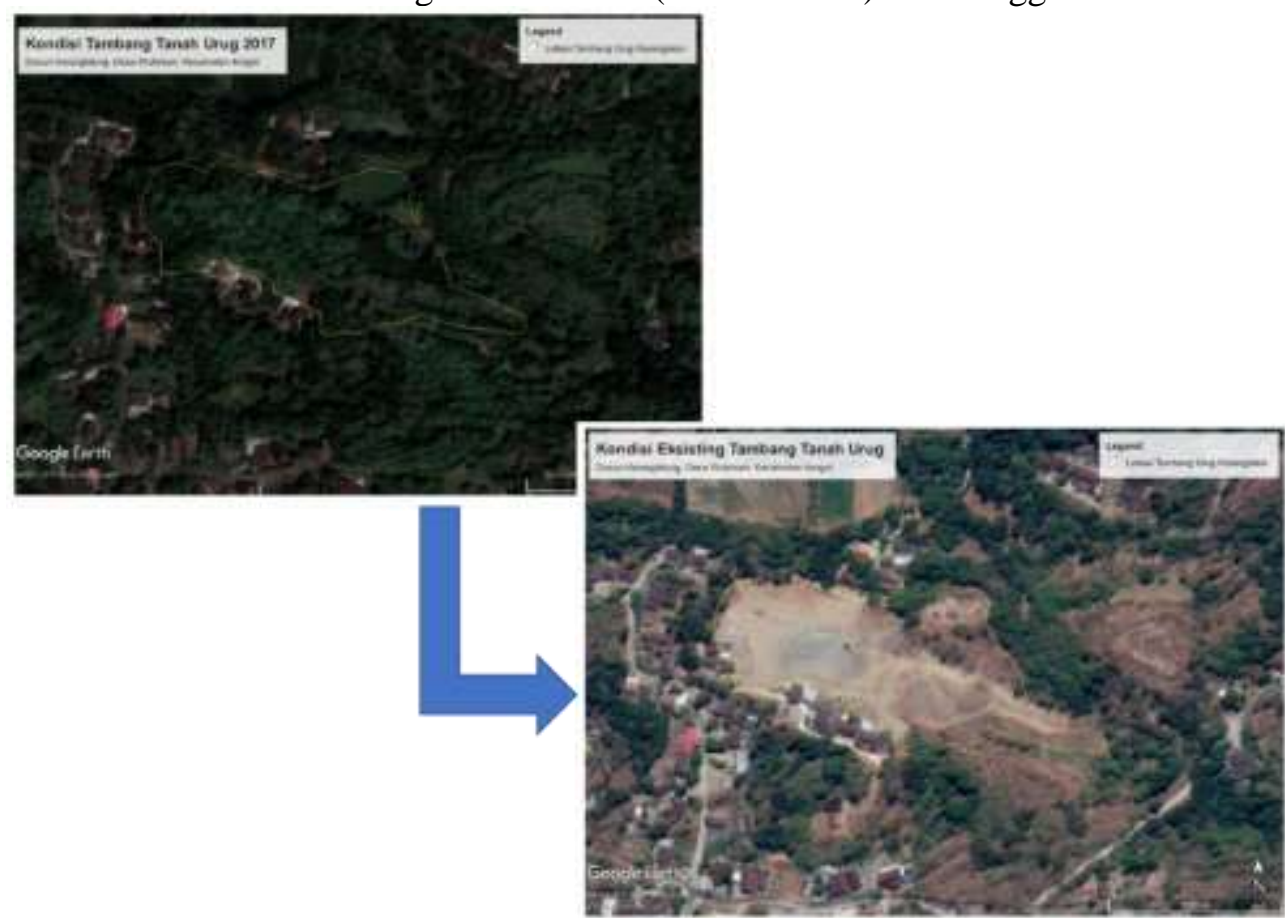

Gambar 3. Perubahan Kondisi Topografi Sebelum dan Sesudah Penambangan 


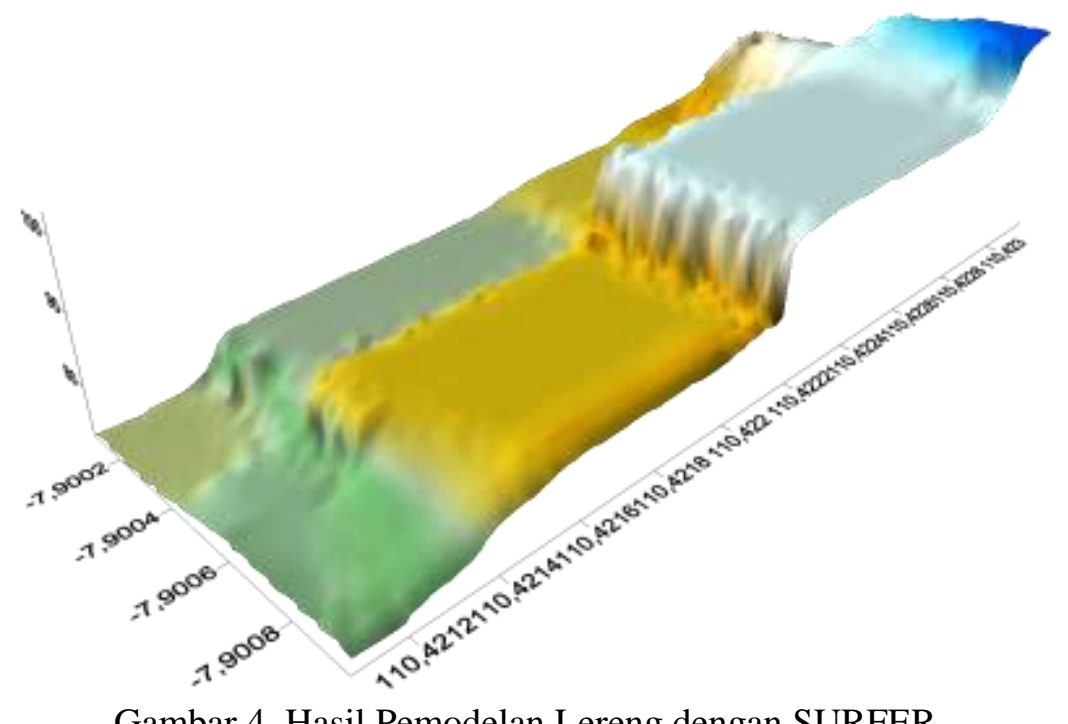

Gambar 4. Hasil Pemodelan Lereng dengan SURFER

Hasil pemodelan lereng menggunakan SURFER menunjukkan kondisi lereng dengan beda tinggi yang besar (>20 meter), dengan persentase kemiringan lereng > 15\% (Agak Curam - Curam) berdasarkan klasifikasi USLE. Berdasarkan pengamatan lapangan dan hasil model tersebut menunjukkan adanya potensi banjir dan longsor di Karangtalun, Imogiri dengan faktor utama yang mempengaruhinya adalah faktor topografi.

\section{Kesimpulan dan Saran}

Analisis sidik cepat kejadian longsor terdahulu, pemodelan lereng, dan pengamatan lapangan menunjukkan faktor potensi longsor lahan di kawasan pertambangan tanah urug adalah dari faktor topografi-lereng, dan kerawanan longsor lahan yang tinggi terdapat di kawasan pertambangan tanah urug di Dusun Karangtalun, Wukirsari, Imogiri, Bantul. Hasil tersebut berasal.

Saran dari penelitian ini adalah diperlukan analisis lebih detil pada kondisi batuan, tanah, dan perubahan penggunaan lahan dan penutup lahan di lokasi penelitian. Diperlukan tambahan parameter dan faktor yang diamati diantaranya penggunaan lahan, pengukuran topografi detil, mekanika tanah dan batuan.

\section{Daftar Pustaka}

Brook, K.N., P. F. Folliot, H.M. Gregesen, dan J.K. Thames. 1991. Hydrology and The Management of Watersheds. Iowa State University Press, Ames USA. 392 pp.

Ganda, I., Roesyanto. 2012. Analisa Stabilitas Lereng Menggunakan Perkuatan Geogrid. Jurnal Teknik Sipil USU Vol 1, No 2 (2012). Sumatera Utara.

Karnawati, D. 2005. Bencana Alam Gerakan Massa Tanah di Indonesia dan Upaya Penanggulangannya. Yogyakarta: Jurusan Teknik Geologi.

Kusratmoko, E. Ludiro, D., Mataburu, L.B., Suripin, Supriatna, Indra, T. L. 2002. Aplikasi Sistem Informasi Geografis untuk Penentuan Wilayah Prioritas Penanganan Bahaya Erosi Studi Kasus DAS Citarum. Jakarta: Jurusan Geografi dan Pusat Penelitian Geografi Terapan Fakultas MIPA Universitas Indonesia.

Nariswari, S.L. 2017. Bandara Kulonprogo : Tanah Urug di Lahan Relokasi Masih Kurang. URL: https://jogjapolitan.harianjogja.com/read/2017/01/31/514/789061/bandara-kulonprogo-tanah-urugdi-lahan-relokasi-masih-kurang. Diakses tanggal 10 November 2019.

Rudiyanto. 2010. Analisis Potensi Bahaya Tanah Longsor Menggunakan Sistem Informasi Geografis (SIG) Di Kecamatan Selo, Kabupaten Boyolali. Skripsi thesis, Universitas Muhammadiyah Surakarta. 
Verruijt, A. 2017. An Introduction to Soil Mechanic. ISSN 0924-6118 ISSN 2213-6940 (electronic), Theory and Applications of Transport in Porous Media, ISBN 978-3-319-61184-6 ISBN 978-3-319-61185-3 (eBook), DOI 10.1007/978-3-319-61185-3

Widyaputra, P.K., Setiawan , M.A. 2015. Analisis Sidik Cepat Kerawanan Banjir Bandang di DAS Juwana Provinsi Jawa Tengah. Prosiding Seminar Nasional Geografi UMS. Surakarta. 